\title{
The influence of job burnout on organizational citizenship behavior of employees in hotels
}

\author{
Jehan El Amir _ - $\quad$ Amr Deraz
}

\author{
Hotel Studies Dep., Faculty of Tourism and Hotels, Sadat City University
}

\begin{abstract}
Hospitality market is faced by strong challenges and competition. Therefore, hotel employees always face fierce stress that may hinder their organizational citizenship behavior and increase the rate of their turnover. So, this paper examines the effect of job burnout on organizational citizenship behavior

(OCB).

A questionnaire form used for this purpose included eight dimensions, named emotional exhaustion; depersonalization; personal accomplishment; altruism ; conscientiousness ; courtesy ; civic virtue; sportsmanship for measuring the relationship between the two variables. A Mann-Whitney U test, a Kruskal-Wallis test, as well as the linear regression analysis were used to analyze the 360 questionnaire forms collected from five star hotels employees. It has been found that Emotional exhaustion, Depersonalization, and Personal accomplishment had significant effects on citizenship behavior. The results suggested that a variety of efforts to assist employees in family concerns, legal issues, financial matters and health maintenance (which is called employee assistance programs) should be employed.

Keywords: organizational citizenship behavior; job burnout; Emotional exhaustion; Depersonalization; Personal accomplishment.
\end{abstract}

\section{Introduction}

Hospitality industry workers are always under continual stress for the need to compete for the rapid changes in the hospitality market .Hotel workers not only must complete their job, but also act beyond their own obligations. So one of the important studied phenomena in organizational psychology research to date is how employees react and respond toward their work demands.

Several researchers (e.g. Kuruu"zu"m et al., 2008; Allan and Dogan, 2016) have identified the antecedents and consequences of burnout. Examples of antecedents that help to raise burnout include diminished job performance, absenteeism, marital and familial disharmony; diminished self-esteem, difficulties in concentration, social isolation, adverse physical symptoms, alcohol and drug abuse ,psychological disorders , desire to leave a job, depression, anger and apathy, etc. (Chang et al.,2000 ; Burke and Greenglass, 2001). burnout consequences include role conflict, role increased ambiguity, workload (Sari and Diane, 2016).

In addition, other researchers (e.g. Yijing et al., 2016; Szu et al., 2016; Sow and Ho,2017) have identified the benefits of OCB. Examples of these benefits that help organization success include improving customer satisfaction, empowering the hotel to adapt more effectively to environmental changes and political life, supporting the hotels' ability to attract and maintain the best workers, continuing committed to it even under difficult circumstances and external threats.

\section{Literature review \\ Burnout definitions}

Burnout is one of the most important dimensions of employees' well-being (Mustafa and Tugba , 2016), it happens when employees experience gradual loss of caring about the people they work with and the job in general (Sari and Diane, 2016). Basically, burnout is a mismatch between what an employee wants to do and what that an employee must do; in other words, burnout arises when there is a significant disharmony between the nature of a person's job and the nature of the person doing the job (Maslach and Leiter, 2005).

Job burnout refers to "a psychological weakness including failure, wearing-out, exhaustion, loss of creativity, and reduced organizational commitment (Halbesleben ,2008). It also refers to physical health problems, including anxiety, depression, sleep disturbance, memory impairment, and neck pain (Mehmet et al., 2016). Burnout is usually caused by a state of chronic and uncontrolled stress resulting from the inability to cope up with stress properly and also as an outcome that results in decreased leisure time "( Sabine, 2017 ).

\section{Burnout dimensions}

There are many studies that classified the burnout into a number of dimensions (Hatinen et al., 2009 ; Lee and Ok, 2012; Tülay et al., 2017) , they classify job burnout into three dimensions as follows exhaustion, cynicism and inefficacy.

Emotional exhaustion (exhaustion) comes in the core of job burnout dimensions. It refers to lack of energy and feeling emotionally drained, fatigued, and taxed or "used up" from the job ( Cordes and Dougherty, 1993). It happens due to weakening of physical, psychological and emotional resources of individuals in dealing with work demands making them unable to provide previous levels of work performance (Murray and Gibbons, 2007).

The second dimension of burnout is depersonalisation (cynicism) which is characterized by negative and cynical attitudes and behaviors towards customers, frustration, loss of idealism, withdrawal from the different aspects of the job (Maslach and Jakson, 1986). It is caused by many factors such as work stress, excessive interpersonal interaction, excessive workload, and the nature of job responsibilities (Patton and Goddard, 2003).

Reduced personal accomplishment (inefficacy) refers to individuals' lack of achievement, skill, sufficiency at work and the feelings of not being effective in interactions with coworkers and clients (Maslach and Leiter, 2005). Reasons of Inefficacy may due to low morale, lack of worth, inability to 
cope, failure to produce results, lack of recognition and positive feedback, unrealistic expectations at work and poor management quality (Zopiatis and Constanti, 2005).

\section{Organizational citizenship behavior (OCB) definitions}

Organizational citizenship behavior is precisely the types of behavior and a human conduct of voluntary action showed by employee in achieving organization goals (Isabel et al., 2016). Therefore, it contributes to organizational effectiveness by maintaining and enhancing the organization's social and psychological environment (Obembe, 2013; Jennifer and Julian, 2017).

Employees can largely contribute to the success of their own organization when they behave as good organizational citizens. Employees who act OCBs are often referred to as good soldiers who are willing to accept changes and find resolutions to problems in a constructive way that benefits the whole organization (Jennifer and Julian, 2017). They put extra effort into their work, help colleagues, and diligently seek better ways to do their work which are generally not associated with monetary payment for the work undertaken (Jonas et al., 2016) . In addition, OCBs positively influence job performance and efficiency, customer satisfaction, financial performance, and revenue growth through increasing coworker or managerial productivity and coordinating activities within work groups (Thomas et al., 2016 ; Yucheng et al., 2017 ; Anna et al., 2017).

\section{Organizational citizenship behavior (OCB) dimensions}

Many researches divided organizational citizenship behavior into a various dimensions (Siripapun, 2016; Wen-Jung, 2016 ; Ali and Cem , 2017). These dimensions are as follows civic virtue , conscientiousness, altruism, sportsmanship and courtesy.

One of the OCB behaviors is civic virtue; the employees who have such behavior are usually involved in a number of activities in their own organization such as social activities, professional nature, attending meetings and the political process of the organization (Zellers et al., 2002).

Another OCB behavior is conscientiousness; it is discretionary behavior of an employee that the organization desires such as cooperation, compliance with organizational rules and regulations (Akinbode, 2011).

Moreover, altruism represents another important dimension of OCB, it is a moral attitude or an optional behavior or taking the initiative to help co-workers or someone in a face-to-face situation or in performance related to their duties (Smith et al., 1983). For examples, helping co-worker with a heavy workload, to complete their duties and increase their effectiveness in the organization (organ, 1988).

Sportsmanship; it is considered as a vital dimension of OCB. It denotes the behavior of an employee that enables him to tolerate grievances and obeying organizational regulations. It also enables the employees face inevitable disturbances and working extortions that may occur in an organization without complaining and doing so with a positive attitude.

Lastly, courtesy the fifth dimension is seen as another important dimension of the OCB behavior. It refers to gestures or discretionary behaviors aiming at preventing future problems adversely affecting in the organization. It also indicates how one's actions affect others (Markoczy et al., 2009).

Other studies classified the OCB into two main dimensions, namely OCBs-organization (OCB-O) and OCBs-individual (OCB-I) (Raub, 2008 ; Kumju and Myeonggil, 2017).

OCB-O refers to positive behaviors and an attitude that helps and directly improves the organization. It involves conscientiousness, civic virtue, and sportsmanship. OCB-O advantages are positive talking about the association to customers and any foreign people ; keeping up with changes in the association, and providing with a new propositions for the establishment's enhancement (Podsakoff et al., 1997).

On the other hand, OCB-I denotes positive behaviors and an attitude targeted at individuals, contributes to the benefit of the association indirectly. It includes altruism and courtesy. OCB-I advantages are assisting co-worker with his or her workload; assisting co-worker with his or her workload (Anderson and Agarwal, 2010).

Thus, the study aims to examine the influence of job burnout dimensions on organizational citizenship behavior dimensions in the hotels. Based on the reviewed literature, the following research framework is needed to be investigated. The following hypotheses can be concluded.

H1: There is a relationship among demographics elements with regard to job burnout dimensions.

$\mathrm{H} 2$ : There is a relationship among demographics elements with regard to OCB dimensions.

H3: There is a relationship among job burnout dimensions and OCB dimensions.

H4: There is a relationship among Emotional exhaustion and OCB dimensions.

H5: There is a relationship among Depersonalisation and OCB dimensions.

H6: There is a relationship among reduced Personal accomplishment and OCB dimensions.

\section{Methodology}

\section{Measurement and Instrument}

A questionnaire of two main parts was designed, the first part contained five sections; altruism (5 items), conscientiousness (3 items), courtesy (4 items), civic virtue (4 items) and sportsmanship (5 items) for measuring organizational citizenship behavior (Podsakoff et al., 1997). The second part contained three sections; depersonalization (4 items), personal accomplishment (6 items) and emotional exhaustion (7 items) to measure job burnout ( Maslach and Jackson, 1986). A 5 point likert scale was used where by 1 refers to completely disagree while 5 refers to completely agree. 


\section{Population and sample}

A total of 600 questionnaire forms were randomly distributed among all five-star hotels in Sharm ElShiekh, but only 10 hotels that represents about $30.3 \%$ accepted to do that. Only 360 complete questionnaires were received, representing a response rate of 60 percent. The questionnaire forms were distributed and collected by hand to the investigated sample of employees during the period from 7 2017 to 9-2017.

\section{Reliability and validity}

Consideration and necessary adjustments made to pre-tested the questionnaire on two occasions by handing it out to human resources specialists and professor of human resources. Based on those responses, we made necessary improvements were made and some mistakes were corrected.

According to Nunnally and Bernstein, (1994) Values exceeding 0.70 is considered as an acceptable reliability. Hence, 0,9 can be accepted to consider the instrument reliable.

\section{Data analysis}

The Statistical Package for Social Sciences (SPSS) for Windows v.16.0 was used to analyze the data descriptively. Descriptive statistics were employed to identify how far job burnout dimensions affect citizenship behavior of hotel employees. In addition, Mann-Whitney and Kruskal-Wallis tests were used at a significance level of $5 \%$ to examine the differences among respondents with regard to the other variables. A regression analysis was used to analyze the data.

\section{Results and Discussion}

Demographics section involved gender, age, position, and educational level. Among the 360 hotel employees, $75.5 \%$ of them were male and $25.5 \%$ were female. About $72 \%$ of hotel employees were aged between 18 and 35, while approximately $28 \%$ of them were aged between 36 and 57 . Also, hotel employees represent different educational level $(88 \%$ University, $10.5 \%$ high school, and $1.5 \%$ post graduate) where; $35.5 \%$ of employees were in the housekeeping department, $55.5 \%$ were in the food and beverage department, and finally $9 \%$ in the front office department.

Table 1: Cronbach's alpha, means and Standard deviation of questionnaire items

\begin{tabular}{|c|c|c|c|c|}
\hline \multicolumn{2}{|c|}{$\begin{array}{l}\text { Organizational citizenship behavior dimensions } \\
\end{array}$} & \multirow{2}{*}{$\begin{array}{c}\begin{array}{c}\text { Cronbach's } \\
\text { alpha }\end{array} \\
.904 \\
\end{array}$} & \multirow{2}{*}{$\begin{array}{r}\text { Mean } \\
2.3\end{array}$} & \multirow{2}{*}{$\begin{array}{c}\begin{array}{c}\text { Std. } \\
\text { deviation }\end{array} \\
.37296\end{array}$} \\
\hline & Altruism & & & \\
\hline $\mathbf{A \mathbf { l } _ { 1 }}$ & Helps others who have heavy workloads & & 1.3 & \\
\hline $\mathbf{A l}_{2}$ & Helps others who have been absent & 904 & 2.1 & 32826 \\
\hline $\mathbf{A l}_{3}$ & Willingly helps others who have work related problems & .904 & 2.8 & 49857 \\
\hline $\mathbf{A l}_{4}$ & Helps orient new people even though it is not required & .904 & 2.8 & .50346 \\
\hline $\mathbf{A l}_{5}$ & Is always ready to lend a helping hand to those around him/her & 904 & 1.7 & .30143 \\
\hline \multicolumn{2}{|r|}{ Courtesy } & .900 & 2.9 & .53322 \\
\hline $\mathrm{C}_{1}$ & Takes steps to prevent problems with other workers & 904 & 1.3 & 24309 \\
\hline $\mathrm{C}_{2}$ & Is mindful of how his/her behavior affects other people's jobs & .904 & 3 & .44887 \\
\hline $\mathrm{C}_{3}$ & Does not abuse the rights of others & .904 & 4.5 & 87121 \\
\hline $\mathrm{C}_{4}$ & Tries to avoid creating problems for coworkers & .904 & 4.6 & .79857 \\
\hline $\mathrm{C}_{5}$ & Considers the impact of his/her actions on coworkers & .887 & 1.3 & 30439 \\
\hline \multicolumn{2}{|r|}{ Civic virtue } & .895 & 1.8 & .26152 \\
\hline $\mathbf{C V}_{1}$ & Attends meeting that are not mandatory, but are considered important & 904 & 1.1 & 22826 \\
\hline $\mathrm{CV}_{2}$ & Attends functions that are not required, but help the company image & .904 & 1.3 & .20439 \\
\hline $\mathrm{CV}_{3}$ & Keeps abreast of changes in the organization & 887 & 3 & 32887 \\
\hline $\mathrm{CV}_{4}$ & Reads and keeps up with organization announcements, memos, and so on & .887 & 1.8 & 28459 \\
\hline \multicolumn{2}{|r|}{ Sportsmanship } & 903 & 2.2 & 37567 \\
\hline $\mathbf{S P}_{1}$ & Consumes a lot of time complaining about trivial matters & .904 & 1.3 & .22132 \\
\hline
\end{tabular}

\begin{tabular}{|c|c|c|c|c|}
\hline $\mathbf{S P}_{2}$ & Always focuses on what's wrong, rather than the positive side & .904 & 1.3 & 20031 \\
\hline $\mathrm{SP}_{3}$ & Tends to make "mountains out of molehills & 904 & 2.4 & .38759 \\
\hline $\mathrm{SP}_{4}$ & Always find fault with what the organization is doing & 902 & 2.8 & .48859 \\
\hline $\mathbf{S P}_{5}$ & Is the classic "squeaky wheel" that always needs greasing & 902 & 3 & .58055 \\
\hline & Conscientiousness & 904 & 4.1 & .91581 \\
\hline $\mathrm{Con}_{1}$ & Obeys company rules and regulations even when no one is watching. & 904 & 3 & .78029 \\
\hline $\mathrm{COn}_{2}$ & I am one of my most conscientious employees. & 904 & 4.8 & .98829 \\
\hline $\mathrm{Con}_{3}$ & Believes in giving an honest day’s work for an honest day's pay. & .904 & 4.6 & .97866 \\
\hline \multicolumn{5}{|c|}{ Burnout dimensions } \\
\hline \multicolumn{2}{|r|}{ Emotional exhaustion } & 894 & 4.1 & .94996 \\
\hline $\mathbf{E m}_{1}$ & I feel emotionally drained from my work. & .904 & 4.4 & .97862 \\
\hline $\mathbf{E m}_{2}$ & I feel used up at the end of the workday. & 904 & 4.6 & .95713 \\
\hline $\mathbf{E m}_{3}$ & $\begin{array}{l}\text { I feel fatigued when I get up in the morning and have to face another day on } \\
\text { the job. }\end{array}$ & 904 & 4 & 90220 \\
\hline $\mathbf{E m}_{4}$ & I feel burned out from my work. & .887 & 4.5 & .97121 \\
\hline $\mathbf{E m}_{5}$ & I feel I'm working too hard on my job. & .887 & 3.8 & .95400 \\
\hline $\mathbf{E m}_{6}$ & I feel frustrated by my job. & .887 & 3 & .93823 \\
\hline $\mathbf{E m}_{7}$ & I feel like I'm at the end of my rope. & .887 & 4.2 & .94833 \\
\hline \multicolumn{2}{|r|}{ Depersonalization } & .904 & 3.8 & .82016 \\
\hline $\mathbf{D e p}_{1}$ & I feel that I treat some customers as if they were impersonal objects. & .904 & 3.3 & .74309 \\
\hline Dep $_{2}$ & I've become more callous toward people since I took this job. & .904 & 3.8 & .80346 \\
\hline Dep $_{3}$ & I worry that this job is hardening me emotionally. & 904 & 4.4 & .96291 \\
\hline Dep $_{4}$ & I don't really care about what happens to some customers. & .904 & 3.5 & .77121 \\
\hline \multicolumn{2}{|r|}{ Personal accomplishment } & .898 & 2.3 & .41093 \\
\hline $\mathbf{P e r}_{1}$ & I can easily understand how my customers feel about things & 904 & 2.1 & .32826 \\
\hline $\mathrm{Per}_{2}$ & I deal very effectively with the problems of my customers. & 904 & 1.3 & .34309 \\
\hline $\mathrm{Per}_{3}$ & I feel I'm positively influencing the lives of others through my work. & 902 & 3 & .77121 \\
\hline $\mathrm{Per}_{4}$ & I can easily create a relaxed atmosphere with my customers. & 904 & 2.5 & .47524 \\
\hline Per $_{5}$ & I have accomplished many worthwhile things in my job. & .887 & 2 & .17781 \\
\hline $\mathbf{P e r}_{6}$ & In my work, I deal with emotional problems very calmly. & .887 & 3 & .37002 \\
\hline
\end{tabular}


Table (1) shows that OCB dimensions represent Altruism, Courtesy, and Civic virtue with a mean of 2.3, 2.9, and 1.8 respectively while Sportsmanship and Conscientiousness are represented with a mean of 2.2 and 4.1. Also the results clarified that burnout dimensions being Emotional exhaustion, Depersonalization, and reduced Personal accomplishment have a mean of $4.1,3.8$ and 2.3. This explains that the job burnout dimensions negatively affect OCB dimensions. These result agrees with Liang (2012).

Also, the results in table (1) clearly state that Altruism dimension $\mathrm{AL}_{3}, \mathrm{AL}_{4}$ shows the highest mean 2.8, while $\mathrm{AL}_{1}, \mathrm{AL}_{2}$ and $\mathrm{AL}_{5}$ have reported 1.3, 2.1 and 1.7. From these findings we can conclude that burnout dimensions negatively affect Altruism. Depersonalization, Personal accomplishment and Emotional exhaustion have a negative effect on Altruism of employees of the hotel, thus confirming results of yucel (2008).

From the same table, it could be noticed that the dimension of civic virtue the $\mathrm{CV}_{3}$, represents the highest mean 3 , while $C V_{1}, C V_{2}$ and $\mathrm{CV}_{4}$ have reported 1.1, 1.3 and 1.8. We can find that job burnout dimensions of Emotional exhaustion and Personal accomplishment have a negative effect on civic virtue, thus supporting Stephanie et.al, (2010) results.

Again, from the tabulated data it can be seen that Sportsmanship $\mathrm{SP}_{1}, \mathrm{SP}_{2}, \mathrm{SP}_{3}, \mathrm{SP}_{4}$ and $\mathrm{SP}_{5}$ mean $(1.3,1.3,2.4,2.8$, and 3 respectively) reflect the fact that job burnout have negatively influenced Sportsmanship in the work environment, Schepman and Zarate (2008) reported the results.

Furthermore, the data indicated that the two dimensions of OCB; Conscientiousness $\left(\mathrm{Con}_{1}\right.$ $\mathrm{Con}_{2}$, and $\left.\mathrm{Con}_{3}\right)$ and Courtesy $\left(\mathrm{C}_{1}, \mathrm{C}_{2}, \mathrm{C}_{3}, \mathrm{C}_{4}\right.$, and $\left.\mathrm{C}_{5}\right)$ means $(3,4.8$, and 4.6), (1.3, 3, 4.5, 4.6, and 1.3 respectively), which indicate a negative influence of job burnout on the two dimensions.

As results indicated, men and women are on an equal footing concerning their OCB, which matches with Chou and Pearson (2011) research. while, disagreeing with Leslie et al., (2013) who found that females would be more likely than males to engage in OCB. On the contrary, job burnout is more influential on women than men, however Seltzer and Numerof (1988) found no significance between gender and job burnout.

In addition, it was found that senior employees are more loyal than their counterparts of young employees regarding OCB, this result agrees with NG and Feldman (2008). On the other hand, Seltzer and Numerof (1988) found that age has no effect on OCB. And also younger employees are more affected by job burnout, as also found by Maslach and Leiter (2005). On the contrary, the study of Dillon and Tanner (1995) found that age has no effect on burnout.

The educational level has a slight effect on OCB and job burnout, as earlier found Ayşe et.al, (2008). On the contrary top management has an additional advantage over subordinates relating to OCB. In other words they are less affected by job burnout.

To indicate the impact of demographics elements as independent variables on job burnout and OCB dimensions as dependent variables, a correlation was measured. The results clearly showed significant relationships among these variables. Concerning the relationships between the employees' demographics and job burnout dimensions, it was clearly noticed that gender and age achieved the highest score of correlation $(R=0.53$, Sig. $=0.01)$ and $(R=0.43$, Sig. $=0.01)$, whereas position got the lowest score $(\mathrm{R}=0.33$, Sig. $=0.000)$.

Table 2: Comparing means of Job burnout and OCB regarding demographics

\begin{tabular}{|c|c|c|c|c|c|c|c|}
\hline & \multicolumn{3}{|c|}{ Job burnout } & \multicolumn{3}{|c|}{ OCB } \\
\hline & & mean & $\begin{array}{c}\text { Std. } \\
\text { deviation }\end{array}$ & $\begin{array}{l}\text { Asymp. } \\
\text { Sig. (2- } \\
\text { tailed) }\end{array}$ & mean & $\begin{array}{c}\text { Std. } \\
\text { deviation }\end{array}$ & $\begin{array}{l}\text { Asymp. } \\
\text { Sig. (2- } \\
\text { tailed) }\end{array}$ \\
\hline \multirow{2}{*}{ gender } & Male & 3.9 & .653 & \multirow{2}{*}{$.53 *$} & 3.4 & .458 & \multirow{2}{*}{$.41 *$} \\
\hline & female & 3.9 & .653 & & 3.9 & .853 & \\
\hline \multirow{2}{*}{ Age } & $\begin{array}{c}\text { Younger } \\
\text { employees }\end{array}$ & 3.5 & .437 & \multirow{2}{*}{$.43^{*}$} & 3.5 & .362 & \multirow{2}{*}{$.33^{*}$} \\
\hline & $\begin{array}{c}\begin{array}{c}\text { Older } \\
\text { employees }\end{array} \\
\end{array}$ & 3.8 & .542 & & 3.8 & .453 & \\
\hline \multirow[t]{2}{*}{ position } & $\begin{array}{c}\text { Top } \\
\text { management }\end{array}$ & 3.5 & .373 & \multirow[t]{2}{*}{$.33 *$} & 3.6 & .459 & \multirow[t]{2}{*}{$.29 *$} \\
\hline & subordinate & 3.3 & .422 & & 3.8 & .358 & \\
\hline \multirow{3}{*}{$\begin{array}{c}\text { Education } \\
\text { al level }\end{array}$} & University & 2.3 & .343 & \multirow{3}{*}{.11} & 2.2 & .363 & \multirow{3}{*}{.01} \\
\hline & High school & 2.1 & .503 & & 2.3 & .342 & \\
\hline & Post graduate & 2.1 & .263 & & 2.2 & .126 & \\
\hline
\end{tabular}

*Correlation is significant at 0.01 (2-tailed).

Regarding the relationships between the employees' demographics and OCB dimensions, it was found that only three demographic elements (i.e. gender, age, and position) had a significant effect on OCB dimensions $(\mathrm{R}=0.41$, Sig. $=0.01) ;(\mathrm{R}=0.33$, Sig. $=0.01) ;(\mathrm{R}=0.29$, Sig. $=0.01)$, as presented in table (2).

\section{Regression between employees' demographics, burnout dimensions and OCB dimensions}

Regression analysis pinpointed which employees' demographics (gender, age, position and educational level) affect job burnout dimensions and OCB dimensions, (Table 3,4) upon measuring the degree of influence of each demographic element on job burnout dimensions by the regression analysis, three items [i.e. (gender) R-square $=.4$, P-value $=.000$; (age) R-square $=.34$, P-value= .000 ; (position) R- 
square $=.300, \mathrm{P}$-value $=.000$ ] were found to significantly affect the relationship between job burnout dimensions, respectively.

In addition, upon assessing the degree of influence of each demographic element on OCB dimensions, three items [i.e. (gender) R-square $=.35$, P-value $=.000$; (age) R-square $=.30$, Pvalue $=.000$; (position) $\mathrm{R}$-square $=.22$, $\mathrm{P}$-value $=.000]$ were found to significantly affect $\mathrm{OCB}$ dimensions, respectively.

Table 3: Demographic elements influencing burnout dimensions

\begin{tabular}{|c|c|c|c|c|}
\hline \multirow[b]{2}{*}{ *Gender } & \multicolumn{2}{|c|}{ Un-standardized Coefficients } & Sig. & Model Statistics \\
\hline & $\mathbf{B}$ & Std. Error & Sig. & \multirow{3}{*}{$\begin{array}{l}F: 6.5321 \\
R 2: 0.400\end{array}$} \\
\hline Constant & .032 & .001 & .000 & \\
\hline OCB dimensions & 0.456 & .014 & .000 & \\
\hline$* *$ Age & B & Std. Error & Sig. & Model Statistics \\
\hline Constant & .026 & .005 & .000 & $F: 5.1623$ \\
\hline OCB dimensions & .013 & .007 & .000 & $R 2: 0.34$ \\
\hline ***Position & B & Std. Error & Sig. & Model Statistics \\
\hline Constant & .435 & .101 & .000 & $F: 15.3402$ \\
\hline OCB dimensions & .062 & .007 & .000 & $R 2: 0.300$ \\
\hline
\end{tabular}

*Regression equation can be formed as gender $=.032+0.456$ burnout dimensions

$* *$ Regression equation can be formed as age $=.026+.013$ burnout dimensions

$* * *$ Regression equation can be formed as position $=.435+.062$ burnout

Table 4: Demographic elements influencing OCB dimensions

\begin{tabular}{|l|c|c|c|c|}
\hline \multirow{2}{*}{${ }^{*}$ Gender } & \multicolumn{2}{|c|}{ Un-standardized Cofficients } & Sig. & Model Statistics \\
\cline { 2 - 4 } & $\mathbf{B}$ & Std. Error & Sig. & \multirow{2}{*}{$F: 3.1011$} \\
\hline Constant & .022 & .001 & .000 & R2: 0.350 \\
\hline OCB dimensions & 0.06 & .0004 & .000 & Model Statistics \\
\hline ***Age & $\mathbf{B}$ & Std. Error & Sig. & F: 0.9065 \\
\hline Constant & .014 & .001 & .000 & $R 2: 0.300$ \\
\hline OCB dimensions & .011 & .003 & .000 & Model Statistics \\
\hline ***Position & $\mathbf{B}$ & Std. Error & Sig. & F:12.3002 \\
\hline Constant & .320 & .098 & .000 & $R 2: 0.220$ \\
\hline OCB dimensions & .066 & .0002 & .000 & \\
\hline
\end{tabular}

*Regression equation can be formed as gender $=.022+0.06$ OCB dimensions.

$* *$ Regression equation can be formed as age $=.014+.011$ OCB dimensions.

$* * *$ Regression equation can be formed as position $=.320+.066 \mathrm{OCB}$ dimensions.

\section{Relationship between burnout dimensions and OCB dimensions}

The relationship between job burnout dimensions as independent variables and OCB dimensions as dependent variables, Table (5) indicated significant relationships among all these variables; positive relationship between job burnout dimensions and organizational citizenship behavior $(\mathrm{R}=0.604$, Sig. $=0.004)$ which means that if job burnout increases, OCB decreases, This finding can agree with that of Cropanzano et al., (2003).

Furthermore, it was clearly noticed that Emotional exhaustion and Depersonalization achieved the highest score of correlation $(\mathrm{R}=0.984$, Sig. $=0.000)$ and $(\mathrm{R}=0.960$, Sig. $=0.000)$, whereas Personal accomplishment got the lowest score $(\mathrm{R}=0.707$, Sig. $=0.000)$.

Table 5: Correlations: burnout dimensions and OCB dimensions

\begin{tabular}{|c|c|c|c|}
\hline & & burnout dimensions & OCB dimensions \\
\hline burnout dimensions & $\begin{array}{l}\text { Pearson correlation } \\
\text { Sig. (2-tailed) } \\
\qquad N\end{array}$ & $\begin{array}{c}1 \\
360\end{array}$ & $\begin{array}{l}.604 \\
.000 \\
360\end{array}$ \\
\hline OCB dimensions & $\begin{array}{l}\text { Pearson correlation } \\
\text { Sig. (2-tailed) } \\
\qquad N\end{array}$ & $\begin{array}{l}.604 \\
.000 \\
360\end{array}$ & $\begin{array}{c}1 \\
360\end{array}$ \\
\hline & & Emotional exhaustion & OCB dimensions \\
\hline Emotional exhaustion & $\begin{array}{l}\text { Pearson correlation } \\
\text { Sig. (2-tailed) } \\
N\end{array}$ & $\begin{array}{c}1 \\
360\end{array}$ & $\begin{array}{l}.984 \\
.000 \\
360\end{array}$ \\
\hline OCB dimensions & $\begin{array}{c}\text { Pearson correlation } \\
\text { Sig. (2-tailed) } \\
N\end{array}$ & $\begin{array}{l}.984 \\
.000 \\
360\end{array}$ & $\begin{array}{c}1 \\
360\end{array}$ \\
\hline & & Depersonalization & OCB dimensions \\
\hline Depersonalization & $\begin{array}{l}\text { Pearson correlation } \\
\text { Sig. (2-tailed) } \\
\qquad N \\
\end{array}$ & $\begin{array}{c}1 \\
360 \\
\end{array}$ & $\begin{array}{l}.960 \\
.000 \\
360 \\
\end{array}$ \\
\hline OCB dimensions & $\begin{array}{l}\text { Pearson correlation } \\
\text { Sig. (2-tailed) } \\
\qquad N\end{array}$ & $\begin{array}{l}.960 \\
.000 \\
360\end{array}$ & $\begin{array}{c}1 \\
360\end{array}$ \\
\hline & & Personal accomplishment & OCB dimensions \\
\hline $\begin{array}{c}\text { Personal } \\
\text { accomplishment }\end{array}$ & $\begin{array}{l}\text { Pearson correlation } \\
\text { Sig. (2-tailed) } \\
\qquad N\end{array}$ & $\begin{array}{c}1 \\
360\end{array}$ & $\begin{array}{l}.707 \\
.000 \\
360\end{array}$ \\
\hline OCB dimensions & $\begin{array}{c}\text { Pearson correlation } \\
\text { Sig. (2-tailed) } \\
N \\
\end{array}$ & $\begin{array}{l}.707 \\
.000 \\
360 \\
\end{array}$ & $\begin{array}{c}1 \\
360 \\
\end{array}$ \\
\hline
\end{tabular}

**Correlation is significant at 0.05 (2-tailed).

\section{Regression between burnout dimensions and OCB dimensions}


Regression analysis described which job burnout dimensions (Emotional exhaustion, Depersonalization and Personal accomplishment) affect OCB dimensions, (table 6). Assessing the degree of influence of each burnout dimension on OCB dimensions based on regression analysis, four aspects [i.e. (Emotional exhaustion) R-square $=.845, \mathrm{P}$-value $=.000$; (Depersonalization) R-square $=.744, \mathrm{P}$-value $=.000$; (Personal accomplishment) $\mathrm{R}$-square $=.702, \mathrm{P}$-value $=.054$; (burnout dimensions) $\mathrm{R}$-square $=.403, \mathrm{P}$-value $=.000]$ were found to significantly affect $\mathrm{OCB}$ dimensions, respectively.

From the regression results, it could be noticed that Emotional exhaustion and Personal accomplishment had the highest impact on OCB dimensions. This finding agrees with the study of Chiu and Tsai (2006) found that Emotional exhaustion, and Personal accomplishment were the most important dimensions influencing OCB dimensions. And also with the study of Mark and Zaiton (2015) who found that Personal accomplishment was the most important dimension influencing OCB dimensions.

Table 6: burnout dimensions influencing OCB dimensions

\begin{tabular}{|c|c|c|c|c|c|}
\hline \multirow[t]{2}{*}{ Variables } & \multicolumn{3}{|c|}{ Un-standardized Coefficients } & \multirow[t]{2}{*}{ Sig. } & \multirow{4}{*}{$\begin{array}{c}\text { Model Statistics } \\
F: 9.33 o 3\end{array}$} \\
\hline & $\mathrm{B}$ & Std. Error & R-square & & \\
\hline * Constant & .055 & .002 & \multirow{2}{*}{0.403} & .000 & \\
\hline burnout dimensions & 0.286 & .094 & & .000 & \\
\hline \multirow[t]{2}{*}{ Variables } & \multicolumn{3}{|c|}{ Un-standardized Coefficients } & \multirow[t]{2}{*}{ Sig. } & Model Statistics \\
\hline & $\mathrm{B}$ & Std. Error & R-square & & \multirow{3}{*}{$F: 14.2803$} \\
\hline **Constant & .046 & .009 & \multirow{2}{*}{0.845} & .000 & \\
\hline **Emotional exhaustion & .033 & .007 & & .000 & \\
\hline \multirow[t]{2}{*}{ Variables } & \multicolumn{3}{|c|}{ Un-standardized Coefficients } & \multirow[t]{2}{*}{ Sig. } & Model Statistics \\
\hline & B & Std. Error & R-square & & \multirow{3}{*}{$F: 6.643 o 3$} \\
\hline$* * *$ Constant & .016 & .006 & \multirow{2}{*}{0.744} & .000 & \\
\hline$* * * *$ Depersonalization & .448 & .050 & & .000 & \\
\hline \multirow[t]{2}{*}{ Variables } & \multicolumn{2}{|c|}{$\begin{array}{l}\text { Un-standardized } \\
\text { Coefficients }\end{array}$} & & \multirow[t]{2}{*}{ Sig. } & Model Statistics \\
\hline & $\mathrm{B}$ & Std. Error & R-square & & \multirow{3}{*}{$F: 16.49 o 2$} \\
\hline$* * * *$ Constant & .565 & .181 & \multirow[b]{2}{*}{0.702} & .000 & \\
\hline 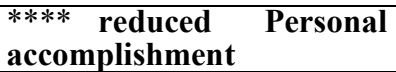 & .500 & .072 & & .000 & \\
\hline
\end{tabular}

\section{Conclusion and recommendations}

The study aims at recognizing the effect of job burnout on organizational citizenship behavior. The results have certified a positive relationship between the two variables. This study could be beneficial for hotel management as follows:

1. Hotel management can overcome work burden by raising employees' morale through many practices as recreational trips and ideal worker contest.

2. From the very beginning human resources managers must apply a recruitment policy that guarantees enthusiastic and loyal employees.

3. Work environment must be positive that encourage quality workers to stay with the hotel, the essential area of concern includes worker safety and health.

4. Communication efforts to have employees voices heard by management

5. High technology training methods are available nowadays in hotel industry, computers make it possible to provide problem solving, simulation, instruction forms and many other sophisticated tutorial methods. 
The influence of job burnout on organizational citizenship behavior of employees in hotels

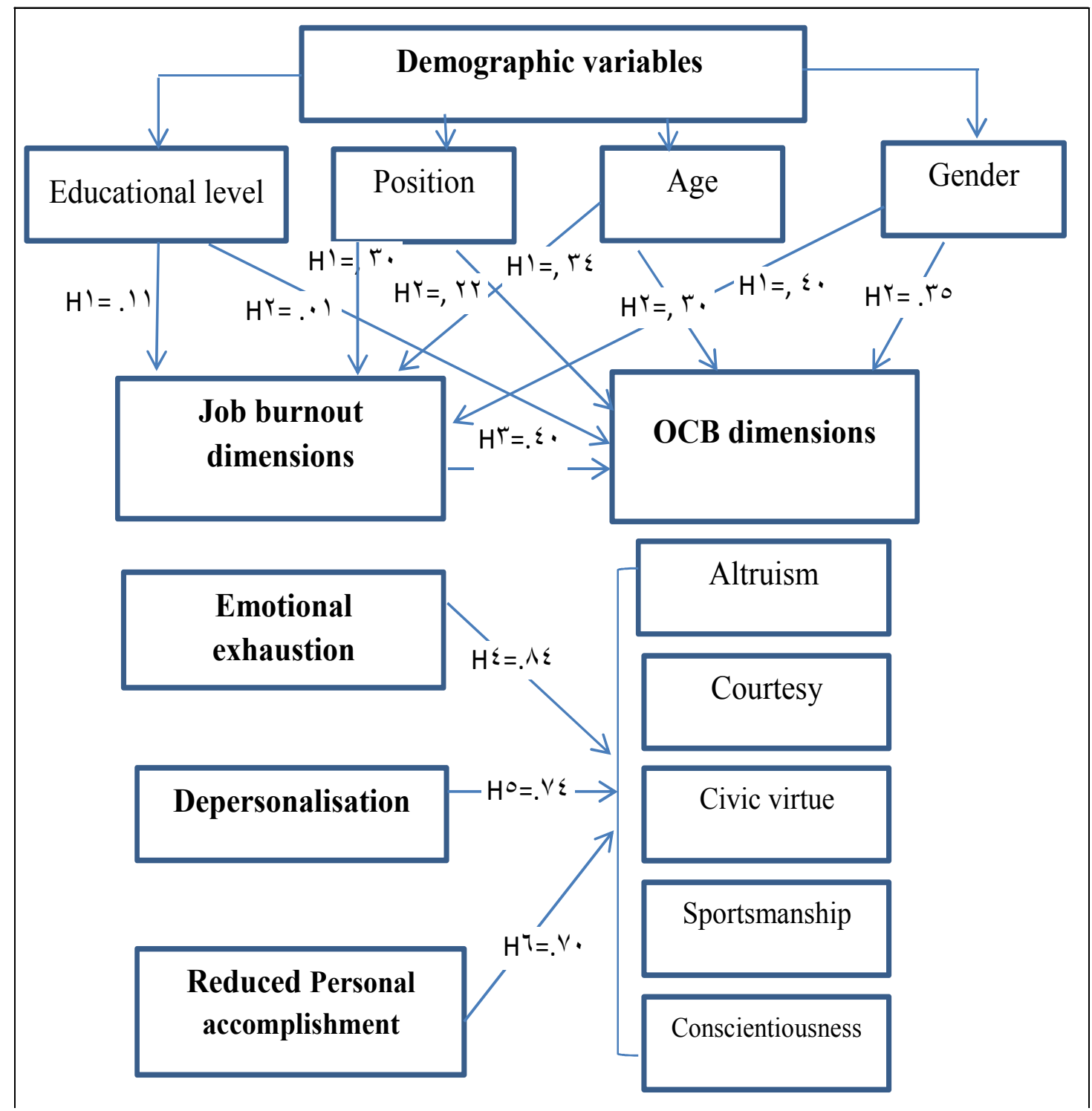

Figure 1: research framework 
Akinbode, G.A. (2011), Demographic and dispositional characteristics as predictors of organizational citizenship behavior; an appraisal of OCB in a non-English culture workgroups. IFE Psychologia, Vol. 19, No. 1, pp. 375-404.

Ali, Ö. and T. Cem (2017), Coaching and employee organizational citizenship behaviours: The role of procedural justice climate, International Journal of Hospitality Management, Vol. 60, pp.58-66.

Allan, C. C. L. and G. Dogan (2016), Impact of Job Burnout on Satisfaction and Turnover Intention: Do Generational Differences Matter?, Journal of Hospitality and Tourism Research, Vol. 40, No. 2, pp.210-35.

Anderson, C. L. and R. Agarwal (2010), Practicing safe computing: Amultimethod empirical examination of home computer user security behavioral intentions, MIS Quarterly.

Anna, G. , D. Geoff, D. Michel, and G. Stephen (2017), The role of interorganizational citizenship behaviors in the innovation process, Journal of Business Research, Vol. 73 , pp.55-64.

Ayse, K. , A. Nilgün, and I. Sezgin (2008), Predictors of burnout among middle managers in the Turkish hospitality industry", International Journal of Contemporary Hospitality Management, Vol. 20, No.2, pp.186-198

Burke, R.J. and E.R. Greenglass (2001), Hospital restructuring and psychological burnout in nursing staff. Equal Opportunities International, Vol. 20 No. 1/2,pp. 61-71.

Chang, C.E., K.L. Rand and D.R. Strunk (2000), Optimism and risk for job burnout among working college students: stress as a mediator. Personality and Individual Differences, Vol. 29, pp. 255-63.

Chiu, S.F. and M.C. Tsai (2006), Relationships among burnout, job involvement, and organizational citizenship behavior. The Journal of Psychology, Vol. 140 , No. 6, pp. 517-30.

Chou, S. Y. and J. Pearson (2011), A Demographic Study of Information Technology Professionals'

Organisational Citizenship Behavior. Journal of Management Research, Vol. 3, No. 2, pp.1-15.

Cordes, D. and T.W. Daugherty (1993), A review and an integration of research on job burnout. Academy of Management Review, vol. 18 , No.4, pp.621-56.

Coyle-Shapiro, J. A., I. Kessler, and J. Purcell (2004), Exploring organizationally directed citizenship behavior: Reciprocity or "it's my job"?. Journal of Management Studies, vol. 41, pp.85-106.

Cropanzano, R., D.E. Rupp and Z.S. Byrne (2003), The relationship of emotional exhaustion to work attitude, job performance, and organizational citizenship behavior. Journal of Applied Psychology, Vol. 88, pp. $160-9$.

Dillon, J.F. and G.R. Tanner (1995), Dimensions of career burnout among educators. Journalism and Mass Communication Educator, Vol. 50 , No. 2, pp. 4-13.

Eagly, A. H., and M. Crowley (1986), Gender and helping behavior: A meta-analytic review of the social psychological literature. Psychological Bulletin, Vol.100, pp.283-308.

Eddleston, K. A., J. F. Veiga, and G. N. Powell (2006), Explaining sex differences in managerial career satisfier preferences: The role of gender self-schema. The Journal of Applied Psychology, Vol.91, pp.437-445.

Gill, A. S., A. B. Flaschner and M. Shachar (2006). Mitigating stress and burnout by implementing transformational-leadership. International Journal of Contemporary Hospitality Management, Vol.18, Vol. 6, pp.469-81.

Hakanen, J., A. Bakker and W. Schaufeli (2006), Burnout and engagement among teachers. Journal of School Psychology, Vol.43, pp.495-513.

Halbesleben, J. R. (2008), The handbook of stress and burnout in health care. Hauppauge, NY: Nova Science Publishers.

Halbesleben, J.R.B. and W.M. Bowler (2007), Emotional exhaustion and job performance: the mediating role of motivation. Journal of Applied Psychology, Vol. 92 , No. 1, pp. 93-106.

Halbesleben, J. and W. Bowler (2005), Organizational citizenship behaviours and burnout. In Handbook of Organizational Citizenship Behaviour: A Review of "Good Soldier" Activity in Organizations. Nova Science Publishers, New York, D.L. Turnipse ed, pp. 399-414.

Halbesleben, J. R. B. and M. R. Buckley (2004), Burnout in organizational life. Journal of Management, Vol.30, No.6, pp.859-79.

Hatinen M., U. Kinnunen, A. Ma“kikangas (2009), Burnout during a long-term rehabilitation: Comparing low burnout, high burnout-benefited, and high burnout-not benefited trajectories. Anxiety, Stress and Coping, Vol.22, No. 3,pp. 341-60.

Isabel, B., M. Eva, and M. Jorge (2016), From internal brand management to organizational citizenship behaviours: Evidence from frontline employees in the hotel industry, journal of Tourism Management Vol.57, pp.256-71.

Jennifer, L. R. and B. B. Julian (2017), Toward a new measure of organizational environmental citizenship behavior, Journal of Business Research ,Vol.75, pp.57-66.

Jonas, D. , H. Joeri, and D. F. Filip (2016), The multiple face(t)s of state conscientiousness: Predicting task performance and organizational citizenship behavior, Journal of Research in Personality, Vol.5, pp.2.

Kumju, H. and C. Myeonggil (2017), Effects of innovation-supportive culture and organizational citizenship behavior on e-government information system security stemming from mimetic isomorphism, journal of Government Information Quarterly,Vol.5, pp. 4-6.

Kuruuzum, A., N. Anafarta and Irmak, S. (2008), Predictors of burnout among middle managers in the Turkish hospitality industry. International Journal of Contemporary Hospitality Management, Vol. 20 No. 2, pp. 186-98.

Lee, J. and C. Ok (2012), Reducing burnout and enhancing job satisfaction: Critical role of hotel employees' emotional intelligence and emotional labor. International Journal of Hospitality Management, Vol. 31, No. $1101-12$.

Lee, R.T. and B.E. Ashforth (1996), A meta-analytic examination of the correlates of the three dimensions of job burnout. Journal of Applied Psychology, Vol. 81, pp. 123-33.

Leslie, L. M., M. Snyder and T. M. Glomb (2013), Who gives? Multilevel effects of gender and ethnicity on workplace charitable giving. The Journal of Applied Psychology, pp98, 49-62.

Liang, Y. W., (2012), The relationships among work values, burnout, and organizational citizenship behaviors: A study from hotel front-line service employees in Taiwan. International Journal of Contemporary Hospitality Management, Vol. 24 No. 2, pp.251-68.

Mark, K. and H. Zaiton (2015), The Role of Flow between Burnout and Organizational Citizenship Behavior (OCB) among Hotel Employees. in Malaysia 2nd Global Conference on Business and Social Science, pp 199 206.

Markoczy, L., D. Vora and K. Xin (2009), Forbearance in organizational citizenship behaviour. The International Journal of Human Resource Management, Vol. 20 , No. 2, pp. 321-47. 
Maslach, C. and M.P. Leiter (2008), Early predictors of job burnout and engagement. Journal of Applied Psychology, Vol.93, No. 3,pp. 498-512.

Maslach, C. and M.P. Leiter (2005), Stress and burnout: the critical research, in Cooper, C.L. (Ed.), Handbook of Stress Medicine and Health, CRC Press, Lancaster, pp. 155-72.

Maslach, C., W. B.Schaufeli and M. Leiter (2001). Job burnout. Annual Review of Psychology, Vol.52, pp.397-422.

Maslach, C., and S. E. Jackson (1986), The Maslach Burnout Inventory ( $2^{\text {nd }}$ ed.). Palo Alto, CA: Consulting Psychologist Press.

Mehmet, A. , C. Serdar, C. Demet, and O. Tolga (2016), The Influence of Organization Support Perceived in Enterprises on Burnout Feeling: A Field Research, Social and Behavioral Sciences, Vol.235 , pp. 427 - 434.

Mesch, D. J., M. S. Brown, Z. I.Moore, and A. D. Hayat (2011), Gender differences in charitable giving. International Journal of Nonprofit and Voluntary Sector Marketing, Vol.16, pp.342-55.

Mustafa, T. and P. tugba (2016), the effects of job-focused and employee-focused emotional labor on burnout in the hospitality industry in turkey, journal of global strategic management, v. 10, n. 2, pp.95-105.

Murray, G. R., and C. Gibbons (2007), Occupational stress in the chef profession. International Journal of Contemporary Hospitality Management, Vol.19, No.2, pp.32-42.

Ng, T.W.H., and D.C. Feldman (2008). The relationship of age to ten dimensions of job performance. Journal of Applied Psychology, 93, 392-423.

Nunnally, J.C. and I.H. Bernstein (1994), Psychometric Theory. McGraw-Hill, New York, USA.

Obembe, D. (2013), Knowledge sharing, sustained relationships and the habitus. Management Learning, Vol.44, No.4, pp.355-72.

Organ, D. W. and K. Ryan (1995), A meta-analytic review of attitudinal and dispositional predictors of organizational citizenship behavior. Personnel Psychology. Special Issue: Theory and Literature, Vol. 48, pp.775802 .

Organ, D.W. (1988), Organizational Citizenship Behaviour: The Good Soldier Syndrome. Lexington Books, Lexington, MA.

Patton, W. and R. Goddard (2003), Psychological distress and burnout in Australian employment service workers: two years on. Journal of Employment Counseling, Vol. 40, No. 1, pp. 2-16.

Peterson, U., E. Demerouti, G.Bergström, M.Samuelsson, M. Asberg and A. Nygren (2008), Burnout and physical and mental health among Swedish health-care workers. Journal of Advanced Nursing, Vol.62, pp.84-95.

Podsakoff, P.M., M. Ahearne and S.B. MacKenzie (1997), Organizational citizenship behavior and the quantity and quality of work group performance. Journal of Applied Psychology, Vol. 82, No.2, pp.262-70.

Podsakoff, P. M., S. B. MacKenzie, R.H. (1994), Organizational citizenship behaviors and sales unit effectiveness. Journal of Marketing Research, Vol.31, pp.351- 63.

Podsakoff, P. M., S. B. MacKenzie, R.H. Moorman and R. Fetter (1990) Transformational leader behaviours and their effects on followers trust in leader, satisfaction, and organizational citizenship behaviours. Leadership Quarterly,Vol.1, pp.107-142.

Raub, S. (2008), Does bureaucracy kill individual initiative? The impact of structure on organizational citizenship behavior in the hospitality industry. International Journal of Hospitality Management, Vol.27, pp.179186.

Sabine, S. (2017), A task-level perspective on work engagement: A new approach that helps to differentiate the concepts of engagement and burnout, journal of Burnout Research Vol.5 , pp.12-20.

Sari, M. and G.T. Diane (2016), How the need for leisure benefit systems as a resource passageways moderates the effect of work-leisure conflict on job burnout and intention to leave: A study in the hotel industry in Quebec, Journal of Hospitality and Tourism Management, Vol.27, pp.4-11.

Schepman, B.S. and M.A. Zarate (2008), The relationship between burnout, negative affectivity and organizational citizenship behavior for human services employees. International Journal of Humanities and Social Sciences, Vol. 2 , No. 4, pp. 216-21.

Smith, C.A., D.W. Organ and J.P. Near (1983), Organizational citizenship behavior: its nature and antecedents. Journal of Applied Psychology, Vol.68, No.4, pp.653-63.

Seltzer, J. and R.E. Numerof (1988), Supervisory leadership and subordinate burnout. The Academy of Management Journal, Vol. 31 , No. 2, pp. 439-46.

Schutte, N., S. Toppinen, R. Kalimo and Schaufeli, W. (2000), The factorial validity of the Maslach Burnout Inventory - General Survey (MBI-GS) across occupational groups and nations. Journal of Occupational and Organizational Psychology, Vol. 73, pp. 53-66.

Stephanie, G. , k. S. heather, Laschingerrn and 1. michael (2010), Journal of Nursing Management, Vol.18, pp.339-48.

Siripapun, L. (2016), Effects of the big-five personality traits and organizational commitments on organizational citizenship behavior of support staff at Ubon Ratchathani Rajabhat University, Thailand, Kasetsart ,Journal of Social Sciences, Vol. 37 ,pp. 104-11.

Sow, H. and Y.I.L. Ho (2017), Understanding the link between communication satisfaction, perceived justice and organizational citizenship behavior, Journal of Business Research, Vol. 70, pp. 214-223.

Szu,Y. L. , C.C. Hsien, C. Heng, and P. Asia (2016), When perceived welfare practices leads to organizational citizenship behavior, Management Review, Vol. 21, pp. 204-12.

Thomas W.H. , a. Ng, S.K. Simon, and C. F. Daniel (2016), Organizational citizenship behavior and counterproductive work behavior: Do males and females differ?, Journal of Vocational Behavior, Vol. 93 , pp.1132 .

Tülay, P. Ü., G. Ayşe, and Y. Adem (2017), The consequences of internal marketing activities on emotional labor in tourism industry, journal of human sciences, Vol.14, No. 2, pp.8-10.

Van Scotter, J.R. and S.J., Motowidlo (1996), Interpersonal facilitation and job dedication as separate facets of contextual performance. Journal of Applied Psychology, Vol.81, No.5, pp.525-31.

Wen-Jung, C. (2016), The model of service-oriented organizational citizenship behavior among international tourist hotels, Journal of Hospitality and Tourism Management, Vol. 29, pp. 24-32.

Yijing, L., Z. Hong, J. Z. Hong, and H. Leqi (2016), Abusive supervision and customer-oriented organizational citizenship behavior: The roles of hostile attribution bias and work engagement, International Journal of Hospitality Management, Vol. 53, pp.69-80.

Yucel, C. (2008), Teacher burnout and organizational citizenship behavior in Turkish elementary schools. Educational Planning, Vol. 17, No. 1, pp. 27-43. 
Yucheng, Z., G. Yongxing, and N. Alexander (2017), Identity judgements, work engagement and organizational citizenship behavior: The mediating effects based on group engagement model, journal of Tourism Management, Vol. 61, pp.190-7.

Zellers, K. L., B. J. Tepper and M. K. Duffy (2002), Abusive supervision and subordinates' organizational citizenship behavior. Journal of Applied Psychology, Vol.87, pp.1068-76.

Zopiatis, A. and P. Constanti (2005), A review and profile of managerial burnout in the hospitality industry of Cyprus.Tourism Today, Vol. 5, pp. 23-35.

\section{تأثير الاحترلق الوظيفي في السلوك التنظيمي للعاملين بالفنادق عمرو دراز جيهان الامير}

نظرا لما يلعبه سلوك المواطنة التظظيمي من دور مهم فى احتفاظ الفنادق بالعاملين الاكفاء الذين يتميزون عن غيرهم بالولاء و الالتزام تجاه فندقهم تحت اى ظروف او أي تهديدات خارجية، كان من الضرورى التعرف على ألى أبعاد

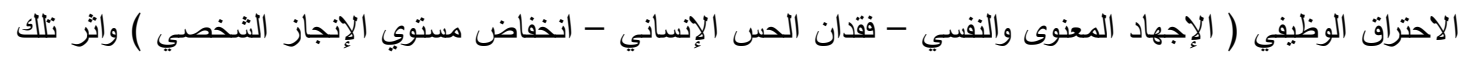

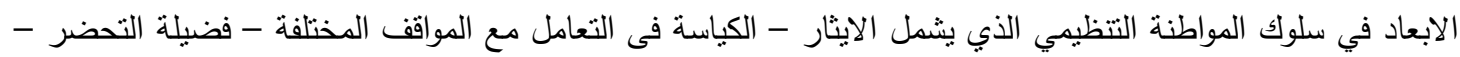
الروح الرياضية ويعني حسن قبول النتائج مها نكن وأخيرا إعمال الضمير فى العمل. ومن خلال استخدام استمارات استقصاء بلغ عددها 360 استمارة موزعة على 10 فنادق بمدينة شرم الثيخ. وتحليلها بواسطة برنامج الحزمة الإنية الاحصائية

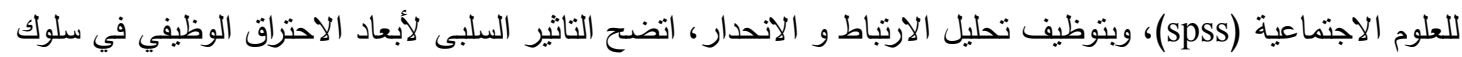

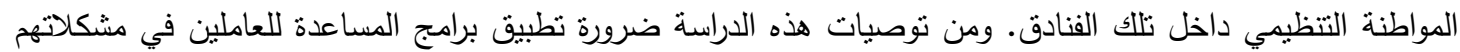
الاسرية والقانونية والمادية والصحية وكذلك خلق بيئة عمل صحية وايجابية لرفع الروح المعنويه والتغلب على الإجهاد

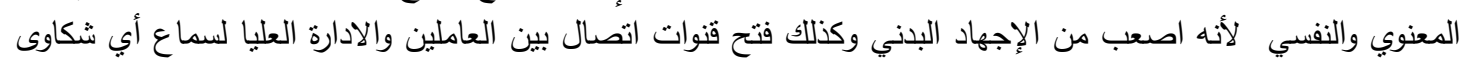
تخصهم ـ كما يجب على الإدارة من البداية نوفير سياسات من شأنها توظيف عاملين يمتازون بالقدرة على الالتزام بسياسة الفندق والولاء ، وأيضا توظيف برامج التكنولوجيا الحديثة فى التدريب والارتقاء بمستوياتهم المهنية.

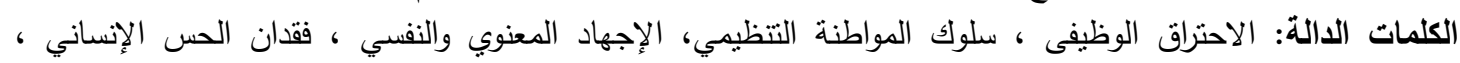
انخفاض مستوى الإنجاز الشخصي. 